\title{
Juha Torvinen
}

\section{JOHDATUS EKOMUSIKOLOGIAAN: MUSIIKINTUTKIMUKSEN VASTUU YMPÄRISTÖKRIISIEN AIKAKAUDELLA}

"Voivatko etnomusikologit pelastaa ympäristön? Meidän on pakko." Näin kirjoitti Timothy J. Cooley (2009) pari vuotta sitten Ethnomusicology-lehdessä. Cooleyn ilmaisema velvoite ei kuitenkaan rajoitu vain etnomusikologeihin vaan koskee kaikkia musiikintutkijoita, kaikkia tutkijoita, kaikkia ihmisiä. Ympäristökriisit, kuten ilmastonmuutos, saasteet, eläinlajien sukupuutto, ydinjäteongelma, sademetsien tuho, ryöstökalastus ja juomaveden puute, ovat nykyisin arkipäiväistä todellisuutta. Viimeistään 1900-luvun viimeisinä vuosikymmeninä kattava ympäristötuho syrjäytti laajamittaisen ydinsodan pahimman uhkakuvan paikalta (Buell 2005: 4-5). ${ }^{1}$

Cooleyn vaatimuksessa ei ole erikoista sen sisältö vaan pikemminkin esittämisen ajankohta. Miksi ympäristöetnomusikologiasta (engl. environmental ethnomusicology; ks. Cooley 2009; Ramnarine 2009) tai ekomusikologiasta (engl. ecomusicology) on alettu puhua toden teolla vasta 2000-luvulla, vaikka luonto on ollut hälyttävässä tilassa jo vuosikymmeniä? Ympäristöliikkeellä ja tunnetuilla ympäristöjärjestöillä on yli 40 vuoden historia ja kansalaisten tietoisuus ympäristöongelmista on ollut tavallista viimeistään 1970-luvulta alkaen. Silti musiikintutkimuksen suhdetta ympäristökysymyksiin on alettu pohtia vasta hyvin hiljattain.

\footnotetext{
I Kiitän Susanna Välimäkeä, Karoliina Lummaata, Kukku Melkasta, John Richardsonia sekä Etnomusikologian vuosikirjan anonyymeja arvioitsijoita käsikirjoituksen kommentoinnista.
}

(c) SES \& Juha Torvinen, Etnomusikologian vuosikirja 2012, vol. 24, ss. 8-34. 
Viime vuosisadan lopulla musiikintutkimus, kuten kulttuurintutkimus ja humanistiset alat yleensäkin, kietoutui vahvasti vallan, sukupuolen, seksuaalisuuden, rodun, etnisyyden, kansallisuuden ja yhteiskuntaluokan teemojen ympärille. Ympäristöongelmien ajateltiin olevan lähinnä luonnontieteen aluetta. Kulttuurintutkimuksessa suosiossa olleen konstruktivistisen käsityksen mukaisesti 'luonto $^{\prime 2}$ saattoi ilmetä humanistille lähinnä diskursiivisena muodosteena: ympäristöongelmat näyttäytyivät pikemminkin yhtenä "suurena kertomuksena" kuin minään todellisena uhkana (ks. Vuorisalo 2012: 29; Coupe 200ob: 2). Jos kulttuurintutkimuksellisten tieteenalojen kirjallisuus olisi ainoa ikkuna vuosisadan lopun todellisuuteen, syntyisi melkeinpä vaikutelma, ettei ympäristökriisejä ole 1900-luvun lopulla ollut olemassakaan (vrt. Glotfelty 1996: xvi; ks. myös Guy 2009: 218).

Musiikintutkimuksen myöhäinen havahtuminen ekokriittiseen tutkimusotteeseen on yllättävää myös siksi, että musiikki itsessään on ollut aina herkkä ympäristön tilan mittari. Esimerkkejä on lukuisia. Marvin Gayen laulussa "Mercy Mercy Me (The Ecology)" vuodelta 1971 pyydetään armoa luonnon saastumisen edessä, ja kolme vuotta myöhemmin kalat kuolivat ja lehdet kellastuivat liian aikaisin Kirkan käännösiskelmässä "Varrella virran" (1973; suom. sanat Pertti Reponen). Biologi Rachel Carsonin aikanaan laajan huomion saaneessa kirjassa Äänetön kevät (alkut. Silent Spring 1962) lintujen laulun vaikeneminen toimii merkkinä ympäristökatastrofista. Beach Boys taas kehotti vuonna 1971 oman surf-musiikki-identiteettinsä kannalta ironisesti "Don't go near the water".

Musiikin ympäristökriittinen rooli on ajan myötä vain korostunut ympäristökriisien saadessa uudenlaisia muotoja 1960- ja 1970-lukujen pääongelman, saastumisen rinnalle. Esimerkiksi progressiivisen rockin yhtye Yes kritisoi ihmisen ylimielisyyttä muita eläinlajeja kohtaan ("Don't Kill the Whale" 1978) ja Iron Maiden ihmettelee eurooppalaista vimmaa hävittää alkuperäiskulttuureja ("Run to the Hills" 1982). Huoli ilmaston lämpenemisestä taas kuuluu niin thrashmetallissa (esim. Testamentin "Greenhouse effect" 1989) kuin Eurovision laulukilpailuissakin (esim. Paradise Oskarin "Da Da Dam" 2011). Monet musiikin tekijät, kuten säveltäjät John Luther Adams (s. 1953) ja Peter Sculthorpe (s. 1929) sekä Cascadian Black Metal -suuntausta edustava yhtye Wolves in a Throne Room, ovat ra-

2 Käytän tässä artikkelissa yksinkertaisia lainausmerkkejä filosofiselle kirjallisuudelle (esimerkiksi niin\&näin-lehti) ominaiseen tapaan korostamaan käsitteitä. 
kentaneet koko musiikillisen eetoksensa ja estetiikkansa ekologisten kysymysten tarkastelulle. Radioheadin kaltaiset kulttibändit ovat pyrkineet hiilineutraaleihin konsertteihin, internet on pullollaan ympäristötietoisia musiikkisivustoja ja Kansas Citystä löytyy jopa artisti nimeltä Eco Elvis, joka tarjoaa camp-henkisen esimerkin musiikin ekokriittisestä kierrättämisestä ja ympäristötietoisuuden levittämisestä lauluillaan "Burning Globe" (alkup. "Burning Love" 1972) ja "Viva Las Vegans" (alkup. "Viva Las Vegas" 1964) jne.

1900-luvun lopulta alkaen on tapahtunut selvä asennemuutos suhteessa ympäristökriiseihin. Muutos on näkynyt yhtä lailla luonnontieteissä, humanistisilla aloilla, filosofiassa ja taiteentutkimuksessa. Ihmistä ja kulttuuria ei enää nähdä luonnonympäristöstä irrallisina eikä luontoa kohdella vain, heideggerilaista ilmaisua käyttääkseni, hyödynnettävänä varantona. Konstruktiivinen käsitys luonnosta on osoittautunut kestämättömäksi ympäristökriisien materiaalis-fyysisen kaikkiallisuuden paineessa. Lisäksi on huomattu se erityisyys, joka ympäristöongelmilla koko maapallon olemassaoloa koskevana kysymyksenä on esimerkiksi ydinsotaan verrattuna: ympäristökriisi ei ole ainoastaan worst case scenario -tyyppinen tulevaisuuden uhkakuva vaan aktuaalista elämäntodellisuuttamme, läsnä tässä ja nyt, kehittyen samalla suuntaan ja laajuuteen, joista ei kenelläkään ole varmuutta.

Samalla ympäristökatastrofit on alettu ymmärtää paitsi materiaalis-fyysisinä myös kulttuurisina ja representaatioihin liittyvinä kriiseinä (Lahtinen \& Lehtimäki 2008b: 15). Biologien, meteorologien ja muiden luonnontieteellisten ympäristötutkijoiden ohella myös humanistisesti orientoituneet (ympäristö)tutkijat ovat nykyisin vahvoja toimijoita ympäristötutkimuksen kentällä, kuten ovat myös ympäristöä taiteen keinoin tutkivat eri alojen taiteilijat (Buell 1995: 3; LummaaVuorisalo-Rönkä 2012: 15-16; Buell 2005: 5; Garrard 2012 [2004]: 6). Ympäristötutkimuksesta on tullut monitieteistä. "Pehmeät" alat - joihin voidaan lukea humanististen ja taidealojen ohella myös yhteiskuntatieteet - ovat ympäristökriisien käsittelyssä avainasemassa siksi, että ne painottavat ympäristöön liittyviä arvokysymyksiä: luonnolle annettuja merkityksiä, ekologisten kriisien psyykkisiä ja yhteiskunnallisia vaikutuksia sekä kriisien eettisen velvoittavuuden astetta. Se miten luontoa esitetään (representoidaan) kulttuurisissa artefakteissa ja diskursseissa, voi olla yhtä hyvin ympäristökriisin syy, seuraus kuin parannuskeinokin. Luonnosta on tullut ekologisten kriisien myötä poliittinen kysymys, jonka kautta 
pohditaan ihmisen suhdetta koko ekosysteemiin. (Lahtinen \& Lehtimäki 2008b: 9; ks. myös Allen 2011a: 391; Tähtinen 2010: 6; Brown \& Toadvine 2003: ix.).

Filosofi Félix Guattari (2008 [1989]) peräänkuuluttaa ekosofiassaan kolmen ekologisen rekisterin - yhteiskunnallisen ekologian, mentaalisen ekologian ja ympäristöekologian - vuorovaikutusta. Ongelma yhdessä rekisterissä on aina ongelma kaikissa rekistereissä, eikä yhtä rekisteriä voi ymmärtää ilman toisia. Vain kaikki ekologiset rekisterit huomioiva tutkimus, joka pohtii myös ympäristön kulttuuris-mentaalisia representaatioita, voi auttaa ymmärtämään esimerkiksi sitä, miksi koko maailma ei satsaa aurinkoenergiaan, vaikka nykyteknologiallakin vain 0,2 prosenttia maapallon pinta-alasta peittävät aurinkopaneelit riittäisivät kattamaan kaiken energiatarpeemme. ${ }^{3}$

Eri ekologiset rekisterit huomioiva ympäristöntutkimuksellinen asennemuutos muodostaa lähtökohdan myös ekokriittiselle musiikintutkimukselle eli ekomusikologialle. Ekomusikologia pohtii kriittisesti kulttuurin ja luonnonympäristön vuorovaikutussuhteiden ilmenemistä musiikissa ja musiikillisissa käytännöissä siinä historiallisessa tilanteessa, jossa nämä vuorovaikutussuhteet ovat osoittautuneet ongelmallisiksi, haavoittuviksi ja essentialisoivien määrittelyjen ulkopuolella oleviksi.

Jos ekomusikologisen tutkimuksen edellytykseksi riittää musiikin ja luonnonympäristön yhteys sinänsä, on alalla yhtä pitkä historia kuin musiikkia koskevilla kirjallisilla luonnehdinnoilla ylipäätään. Onhan luonto vanhimpia musiikin aiheita aina Orfeus-myytistä ja pythagoralaisesta harmoniakäsityksestä romantiikan luonnonmystiikkaan ja cageläiseen äänen emansipaatioon. Alan historia näyttäytyy pitkänä myös silloin, jos sen edellytyksenä pidetään jonkinlaista ekologista tarkastelukulmaa ääni-ilmiöihin ylipäätään (ks. esim. Murray Schafer 1994 [1977]). Mutta vaikka termiä "ekomusikologia" on käytetty jo 1970-luvun

3 Laskelma perustuu siihen, että ihmiskunnan kuluttama energiamäärä on noin o,02 prosenttia siitä energiamäärästä, joka auringosta maahan tulee sekä siihen, että nykyisillä menetelmillä aurinkoenergiasta voidaan hyödyntää noin 10 prosenttia. (Ks. <http://en.wikipedia.org/wiki/World_ energy_resources\#Solar_energy>; kiitän vтт:n tutkija Hannu Välimäkeä asian selventämisestä.) Tosin on muistettava, että ainakin syväekologinen kritiikki toteaisi, että energiansaannin turvaaminen teknologialla on ongelmallista, sillä juuri teknologian kehitys on johtanut moniin ympäristöongelmiin - ei vähiten fossiilisten energialähteiden hyödyntämisen myötä. 
alkupuolella, on se muotoutunut itsenäiseksi musiikintutkimuksen alaksi vasta 2000-luvun taitteessa (ks. Allen [tulossa]).

Kasvavasta kiinnostuksesta alaa kohtaan kertovat viimeaikaiset konferenssit, tutkijaverkostot, alaa koskevat blogit sekä julkaisut. Green Letters julkaisee aiheesta teemanumeron (vol. 15) ja Journal of the American Musicological Society on julkaissut ekomusikologisen kollovion esitelmiä (vol. 64 (2)). Teemaa on käsitelty myös Ethnomusicology- (ks. Cooley 2009; Guy 2009; Ramnarine 2009) ja The World of Music -lehdissä (ks. Titon 2009) ja muutamia aihepiiriin liittyviä antologioita on tekeillä. Myös ekomusikologiaa käsitteleviä monografiatutkimuksia on alkanut ilmestyä (Pedelty 2012). Muutaman vuoden ajan American Musicological Societyssa toimiva Ecocriticism Study Group (2012) on ollut alan keskeinen keskustelufoorumi. Kiinnostus on noussut myös Suomessa: Suomen musiikintutkijoiden 16. symposiumin yhteydessä Jyväskylässä 22.3.2012 järjestettiin maamme ensimmäinen ekomusikologia-teemasessio ja Turun yliopiston musiikkitieteen oppiaineessa on käynnistetty ekomusikologinen tutkimusprojekti. Perusorientaatiossaan ekomusikologiaa lähelle tulee myös akustinen ekologia, jonka perustehtäviä on osoittaa, kuinka luonnon- ja kulttuuriympäristön muutokset vaikuttavat äänimaisemiin ja miten nämä muutokset suhteutuvat, esimerkiksi, kulttuurisen kestävyyden periaatteisiin (ks. esim. Itä-Suomen yliopiston "Soundscape and Cultural Sustainability" -tutkimusprojekti). Jätän akustisen ekologian ja/tai äänimaisematutkimuksen suhteen ekomusikologiaan kuitenkin tässä artikkelissa tarkemman käsittelyn ulkopuolelle.

Tässä artikkelissa esittelen ekomusikologisen tutkimuksen metodologisia lähtökohtia: mitä ekomusikologia kysyy, mihin se pyrkii, mitä menetelmiä se käyttää ja millaisia sen tyypilliset tutkimuskohteet ovat? Koska kyse on ekomusikologiasta, on huomioni pääasiassa musiikissa, vaikka monet ekomusikologiset periaatteet ovat sovellettavissa laajemminkin äänellisen kulttuurin tutkimiseen. Käytän artikkelissani termejä "ympäristö", "luonto" ja "luonnonympäristö" synonyymeinä viittaamaan ei-inhimilliseen fyysiseen todellisuuteen. Käsitteellä "ekologinen" (engl. ecological) viittaan siihen kokonaisuuteen, jossa kaikki liittyy kaikkeen ja johon kuuluu yhtä lailla inhimillinen kuin ei-inhimillinenkin maailma. "Ympäristöllinen" (engl. environmental) puolestaan tarkoittaa artikkelissa lähinnä ihmisen ulkopuoliseen todellisuuteen liittyvää. Kulloisestakin asiayhtey- 
destä käy ilmi, mikäli viittaan termeillä "ympäristö" tai "ympäristöllinen" myös rakennettuun, yhteiskunnalliseen tai kulttuuriseen kokonaisuuteen.

\section{Mitä ekomusikologia kysyy?}

Ekomusikologian peruslähtökohtana on se, että ympäristökriisit ovat nykypäivänä laajimmalle levinnyt tulevaisuuden uhkakuva ja että nämä kriisit vaikuttavat enemmän tai vähemmän kaikkiin ihmisiin kulttuurista, etnisyydestä, sukupuolesta, kansallisuudesta tai yhteiskuntaluokasta riippumatta. Tämä kaikkiallisuus ilmenee myös siinä, että ekomusikologisen tutkimuksen kohteena voi olla kaikenlaiset musiikit, musiikkikulttuurit ja musiikin tekemisen muodot. Keskeistä on selvittää, millaisia merkityksiä luonnolle kyseessä olevan musiikin tai musiikillisen käytännön voidaan tulkita kantavan ja millaisista luonnonympäristöön liittyvistä merkityksistä ja arvokysymyksistä tutkimus voi valitsemiensa kohteiden ja menetelmien avulla neuvotella.

Ekomusikologia on metodologinen sateenvarjokäsite, joka kattaa erilaisia tapoja ymmärtää musiikki sekä valita käytettävät teoriat ja menetelmälliset välineet. Vaikka ala ankkuroituu pääasiallisesti musiikintutkimukseen, ottaa se monitieteisessä ja tieteidenvälisessä hengessä vaikutteita, käsitteitä ja välineitä muun muassa filosofiasta, kirjallisuudentutkimuksesta, kulttuurimaantieteestä, biologiasta ja sosiologiasta. Musiikintutkimuksen sisällä ekomusikologia ammentaa muun muassa äänimaisematutkimuksesta, kulttuurisesta musiikintutkimuksesta, etnomusikologiasta, musiikkianalyysista, musiikin semiotiikasta, eläinten musiikillista käyttäytymistä tutkivasta zoomusikologiasta, populaarimusiikin tutkimuksesta ja audiovisuaalisuuden tutkimuksesta (ks. Allen [tulossa]).

Ekomusikologiassa on kentän nuoresta iästä huolimatta (tai ehkä juuri siitä johtuen) julkaistu runsaasti alan yleistä luonnetta, menetelmiä ja tavoitteita kartoittavia kirjoituksia (Harley 1996; Rehding 2002 \& 2011; Torvinen 2009b; Allen 2011a, 2011b ja [tulossa]; Pedelty 2011 \& 2012; ks. myös Adams 2009). Seuraavat viisi kysymystä luonnehtivat alan orientaatiota. Ne saavat erilaisia, rajatumpia muotoiluja yksittäisten tutkimusten tapauksissa. 
1) Miten musiikki ja musiikkikulttuuri heijastaa, muokkaa ja kritisoi ihmisen suhdetta fyysiseen ympäristöönsä?

2) Miten eri musiikin muodot ja käytännöt poikkeavat toisistaan suhteessa erilaisiin ympäristöllisiin kriiseihin?

3) Millaisia yleisiä musiikillisia strategioita, keinoja tai vakiintuneita kuvastoja eri musiikin lajit käyttävät ympäristöön liittyvien sisältöjen kommunikoinnissa?

4) Onko musiikissa sellaisia kokemuksellisia ulottuvuuksia, jotka tekevät siitä jollain tavalla erityisen ilmiön ympäristökysymysten käsittelyssä?

5) Mikä on musiikin ja musiikintutkimuksen kulttuurinen, poliittinen ja kasvatuksellinen vastuu ympäristökriisien aikakaudella?

\section{Ekokritiikistä tiede- ja teoriakritiikkiin}

Kuten Aaron S. Allen (2011a: 393) on todennut, ekomusikologia ei ole varsinaisesti ekologista musiikintutkimusta vaan ekokriittistä musiikintutkimusta. Jos ekomusikologian taustalta erotetaan tutkimusalue, joka sen muotoutumiseen on eniten vaikuttanut, voidaan sellaisena pitää ekokriittistä kirjallisuudentutkimusta. Ekokritiikkiä voidaan pitää alana, joka alkoi ensimmäisenä pohtia systemaattisesti taiteen ja muiden kulttuuristen ilmiöiden suhdetta vaarantuneeksi koettuun fyysiseen luonnonympäristöön. Termi "ekokritiikki" vakiintui yleiseen käyttöön Cheryll Glotfeltyn ja Harold Frommin vuonna 1996 toimittaman antologian The Ecocriticism Reader: Landmarks in Literary Ecology myötä (Glotfelty \& Fromm 1996). Sittemmin on julkaistu useita ekokritiikin historiaa ja menetelmiä käsitteleviä kirjoja (ks. esim. Buell 1995 \& 2005; Coupe 2000a; Garrard 2012 [2004]; Lahtinen \& Lehtimäki 2008a; Goodbody \& Rigby 2011). Musiikintutkimuksen ohella ekokriittinen lähestymistapa on vaikuttanut muun muassa elokuvien tutkimiseen, mainosten analysointiin, poliittisen retoriikan erittelyyn sekä eläintarhojen, arkkitehtuurin, teemapuistojen ja ostoskeskusten tutkimiseen (Garrard 2012 [2004]: 5; Lahtinen \& Lehtimäki 2008b: 15-16).

Ekokritiikissä on kyse sen tutkimisesta, mitä merkityksiä luonnonympäristölle annetaan, sekä siitä, miten nämä merkitykset vaikuttavat tapoihimme kohdella 
luontoa ja ympäristöä (Lahtinen \& Lehtimäki 2008b: 8). Glotfeltyn (1996: xviii) määritelmän mukaan ekokritiittinen kirjallisuudentutkimus on

\begin{abstract}
kirjallisuuden ja fyysisen ympäristön välisen suhteen tutkimista. Aivan kuten feministinen kritisismi tutkii kieltä ja kirjallisuutta sukupuolitietoisesta näkökulmasta ja marxilaiseen kritisismiin sisältyy tietoisuus tuotantomuodoista ja taloudellisista luokista, ekokritiikkiin sisältyy maa-keskeinen lähestymistapa.
\end{abstract}

Lahtinen ja Lehtimäki (2008b: 14) täsmentävät, että Glotfeltyn maa-keskeinen (engl. earth-centered) lähestymistapa tarkoittaa luonto- ja ympäristökeskeistä perspektiiviä. Vertaus marxilaiseen ja feministiseen tutkimukseen kertoo myös sen ekomusikologiankin kannalta keskeisen seikan, että ekokritiikki on luonteeltaan avoimen poliittinen lähestymistapa (ks. Garrard 2012 [2004]: 3).

Ekokritiikin keskeinen ajatus on, että fyysinen maailma ja inhimillinen kulttuuri ovat jatkuvassa vuorovaikutuksessa keskenään ja että tämä vuorovaikutus (tai sen huomiotta jättäminen) on johtanut kriiseihin, jotka vahingoittavat maapallon ekosysteemiä peruuttamattomasti. Kulttuuriset tuotokset ylläpitävät ja muokkaavat käsityksiämme luonnosta ja ympäristöstä. Siksi ekokritiikillä on tärkeä tehtävä ja vastuu kahdessa merkityksessä. Yhtäl̈ltä se kykenee täydentämään luonnontieteellisen ympäristöntutkimuksen (ekologiassa, biologiassa, geologiassa, maantieteessä jne.) tuloksia kulttuurisilla, poliittisilla ja aina yksilötasolle ulottuvilla kokemuksellisilla merkityksillä. Toisaalta ekokriittinen ote auttaa luonnontieteellistä tutkimusta edellyttävien yhteiskunnallisten, kulttuuristen ja subjektiivisten ympäristöön liittyvien kipupisteiden osoittamisessa. Tämä luonnontieteellisen tutkimuksen ja "pehmeiden" alojen välinen vuorovaikutussuhde on linjassa edellä mainitun Guattarin ajatuksen kanssa, jonka mukaan kolme ekologista sfääriä - ympäristöllinen, yhteisöllinen ja subjektiivinen - eivät ole koskaan erotettavissa toisistaan. Kyse on olennaisesti siitä, että ekokritiikki neuvottelee inhimillisen ja ei-inhimillisen suhteesta tavalla, jossa sellaiset käsitteet kuin 'inhimillinen' ja 'luonto' ovat nekin jatkuvan kriittisen keskustelun alaisia (ks. Garrard 2012 [2004]: 5, 10; Glotfelty 1996: xix; vrt. Morton 2007).

Vaikka ekokritiikki on saanut suhteellisen vankan jalansijan humanististen alojen ja erityisesti kirjallisuudentutkimuksen piirissä, varsinaisesta ekokriittisestä teoriasta on alettu puhua vasta aivan viime aikoina. Tähän on ollut yhtenä 
syynä se, että ympäristön materiaalista, konkreettista todellisuutta korostava ekokritiikki ei ole kokenut omakseen syntyajankohtanaan muodissa olleita konstruktivistisia teorioita, joiden mukaan käsityksemme luonnosta rakentuu puhtaan diskursiivisesti ja luonto on olemassa vain merkittynä (Coupe 20oob: 2; Rigby \& Goodbody 2011: 2). Tieteelle ominainen teoretisointi ylipäätään on voinut tuntua ristiriitaiselta ihmisen ja fyysisen maailman vuorovaikutussuhdetta painottavaan ekokritiikkiin nähden. Ekokritiikin teoretisoimattomuuteen liittyy myös se, että ala on epäyhtenäinen liike, jossa on eri tavoin painottuneita koulukuntia, kuten environmentalismi, ekofeminismi, syväekologia, ekomarksismi, sosiaalinen ekologia ja heideggerilainen ekofilosofia (Lahtinen \& Lehtimäki 2008b: 11; Garrard 2012: 18-36). Lisäksi integroivien teorioiden puuttuminen on osin seurausta myös siitä, että ekokritiikin (ja ekomusikologian) tutkimuskohteet ovat usein konkreettisia, materiaalisia ja käytännöllisiä kysymyksiä (vrt. Slovic 2000: 162).

\section{Ekomusikologisen tutkimuksen peruspiirteitä}

Kaikki musiikintutkimus, joka käyttää ekologia-termiä, ei ole automaattisesti ekomusikologiaa, sillä ekologia-käsitteen käyttö ei välttämättä tuo mukanaan ekokriittistä ja ympäristön tilasta huolta kantavaa peruseetosta. Esimerkiksi Eric F. Clarken (2005) ekologinen lähestymistapa musiikilliseen havaintoon korostaa ekologian periaatteiden mukaisesti radikaalia kontekstuaalisuutta eli kaiken liittymistä kaikkeen muuhun, muttei ota poliittis-aktivistisesti (eli ekokriittisesti) kantaa siihen, millainen luonnonympäristön tila on, millainen sen pitäisi olla tai, ennen kaikkea, miten asioita pitäisi muuttaa ympäristön tilan parantamiseksi.

Erotan seuraavassa viisi ekomusikologisen tutkimuksen kriittistä luonnetta painottavaa peruspiirrettä. Kuten edellä määrittelemieni ekomusikologian peruskysymysten tapauksessa myös näiden piirteiden suhteen on muistettava, että tutkimuksen ekomusikologisuus ei edellytä niiden kaikkien yhtäaikaista läsnäoloa samassa tutkimuksessa. Piirteet eivät myöskään ole luonteeltaan saman tason ilmiöitä, vaan osa niistä liittyy menetelmiin, osa tutkimuskohteisiin ja niiden valintaan, osa yleiseen tutkimukselliseen motivaatioon ja tutkimuspoliittisiin tavoitteisiin. Ehdottamani viisi ekomusikologisen tutkimuksen peruspiirrettä ovat 
1) poliittisuus ja aktivismi, 2) kestävyyden periaate, 3) topofilia, 4) affektiivisuus sekä

5) ekokriittinen ylitulkinta.

\section{Poliittisuus ja aktivismi}

Ekomusikologian raison d'etre ei ole jokin erityinen musiikin tai musiikillisen käytännön muoto, ei edes "vihreän" musiikin olemassaolo, vaan ympäristön huolestuttava tila. Ekomusikologia profiloituu musiikintutkimuksen kentällä omaksi suuntauksekseen ennen kaikkea siten, että sen perusmotivaatio on ajankohtaisissa, laajoissa ja pikaista reagointia vaativissa maailmanlaajuisissa ympäristökriiseissä. Se pyrkii kohti yleistä tietoisuuden lisäämistä, kohti tutkimustulosten käytännön soveltamista (praksista marxilaisessa merkityksessä) sekä kohti yleistä aktivismia. (Rehding 2011: 410.)

Suora tai välillinen vaikuttamispyrkimys tieteen ulkopuolisiin käytäntöihin on luonnehtinut toki myös esimerkiksi feminististä musiikintutkimusta, queermusikologiaa, etnomusikologiaa ja postkolonialistista musiikintutkimusta sekä äänimaisematutkimusta. Itse asiassa sosiaalinen vaikuttamispyrkimys on kuulunut kaikkeen kulttuuriseen ("kriittiseen" tai "uuteen") musiikkitieteeseen, jota on luonnehtinut irtautuminen itseriittoisuutta korostavasta musiikki- ja teoskäsityksestä. Ympäristökriisejä voidaan kuitenkin pitää siinä mielessä vielä suuremman luokan ongelmana, että - kuten edellä mainitsin - ne koskevat kaikkia ja vaikuttavat viime kädessä kaikkiin sukupuoleen, etnisyyteen, kansallisuuteen, ikään, seksuaalisuuteen, musiikkimakuun tai poliittiseen kantaan katsomatta. Tässä mielessä ekomusikologia saattaa olla radikaalein kriittisen musiikintutkimuksen osa-alue: kysymyksiä sukupuolesta, luokasta, etnisyydestä ynnä muusta ei voi edes esittää sen paremmin musiikissa kuin muutenkaan, jos koko biosfääri tuhoutuu (ks. Coupe 200ob: 5).

Jos ekomusikologian peruspyrkimys pureutua musiikin ja äänellisen kulttuurin arvoihin, arvostuksiin ja kulttuurisiin sisältöihin on yksi syy lukea ala osaksi kulttuurista (kriittistä) musiikintutkimusta, on toinen syy se, että ekomusikologiassa kriittisyys toimii yhtäaikaisesti tutkimuksen motivaationa, menetelmänä, kohteena ja tavoitteena. Ekomusikologiaan soveltuu se, mitä Laurence Coupe (20oob: 4) on todennut green studies -tutkimusalasta: ekomusikologia on uudenlaista pragmatiikkaa. Samalla kun se pohtii sitä, miten musiikissa viitataan luon- 
toon, se käyttää 'luontoa' kriittisenä käsitteenä. Pitämällä luonnonympäristöä ja sen kriittistä tilaa tutkimuksen keskiössä ekomusikologia haastaa industrialismin ja teknologisen edistysuskon (sikäli kun tieteellinen tutkimus voi ylipäätään olla ei-teknologista) sekä sosiaalisen konstruktivismin, jolle 'luonto' on lähinnä diskursiivinen muodostelma. Ekomusikologian korostunut ja monikerroksinen kriittisyys nousee siitä, että luonnonympäristö on kriittisessä tilassa ja että musiikkia voidaan kuunnella ja tutkia kriittisinä kannanottoina juuri tähän kriittiseen tilaan. Jos tutkimus ei pyri vaikuttamaan tietoisuuteen tästä kriittisestä tilasta eli jos se ei pyri vaikuttamaan ihmisten käyttäytymiseen ja arvoihin, se ei ole täydessä merkityksessä ekokriittistä musiikintutkimusta (vrt. Coupe 200ob: 4).

\section{Kestävyyden periaate}

Yksi ekomusikologinen tutkimustapa kiinnittyy kestäoyyden ja kestävän kehityksen käsitteisiin. Kestävällä kehityksellä tarkoitetaan yleisesti ottaen pyrkimystä toimia niin, että ihmiskunnan tarpeiden tyydyttäminen ei vaarantaisi tulevien sukupovien elinehtoja. Käsitteen kehittäjänä pidetään Norjan entistä pääministeriä ja ҮK:n ympäristön ja kehityksen maailmankomission entistä puheenjohtajaa Gro Harlem Brundtlandia. Kestävän kehityksen ajatusta on sovellettu niin ekologisiin, taloudellisiin, sosiaalisiin kuin kulttuurisiinkin kysymyksiin (ks. Lummaa, Vuorisalo \& Rönkä 2012: 2). Kestävän kehityksen ajatusta soveltavat tutkimukset eivät siis välttämättä tarkastele ainoastaan ympäristön tilaa, mutta noudattavat kuitenkin niitä periaatteita, jotka ovat nousseet alun perin vahvasti juuri ympäristön tilan huomioinnista.

Kestävän kehityksen kritisoijat voivat puuttua käsitteen ilmentämään antroposentrisyyteen, sillä kestävyys ymmärretään usein lähinnä ihmisen tarpeiden näkökulmasta - hirven, saunamaijan, valkovuokon, homesienen tai moreenin kannalta kestävä kehitys olisi erilaista. Toisaalta koko ajatus kehityksestä on ideologinen, rajoittuneen teknis-taloustieteellinen, minkä vuoksi kestävän kehityksen sijaan on alettu viime aikoina puhua lyhyemmin kestävyyden (engl. sustainability) periaatteesta, joka painottaa eri olemassaolon muotojen itseisarvoisuutta ja pyrkii välttämään yhdenmukaistavia näkökulmia, kuten "kehitys".

Jeff Todd Titon (2009) on tarkastellut kestävyyttä musiikkikulttuurien kontekstissa. Tällöin pohditaan esimerkiksi musiikkikulttuurien, harvinaisten mu- 
siikki- tai soittotyylien tai perimätietona siirtyneiden soitinrakennustaitojen säilymisen ehtoja. Titonin mukaan voimme soveltaa musiikkikulttuurien olemassaolon tutkimiseen neljää keskeistä ekologista periaatetta: 1) monimuotoisuuden itseisarvoisuus, 2) jatkuvan kasvupyrkimyksen tunnistaminen kestämättömäksi periaatteeksi (vrt. kestävä kehitys -käsitteen kritiikki), 3) kaikkien (musiikkikulttuurin) osatekijöiden olemuksellinen vaikutussuhde kaikkiin toisiin osatekijöihin sekä 4) huolenpito (engl. stewardship), joka viittaa siihen, että ihminen on omistamisen ja hyödyntämisen sijaan velvoitettu pitämään huolta (musiikki)kulttuurin osatekijöistä. (Titon 2009; ks. myös Sustainable Music 2012).

Kestävyyden ajatusta voidaan soveltaa musiikin tutkimiseen myös muilla tavoin. Esimerkiksi soitinrakennus on jo vuosisatojen ajan hyödyntänyt erilaisia kasvi- ja eläinkunnan tuotteita niiden soinnillisten ominaisuuksien, lujuuden, koristelutarkoituksiin soveltuvuuden tai jonkin uskonnollisen tai maagisen merkityksen vuoksi. Tämä hyödyntäminen on kuitenkin monella tapaa ekologiselta kannalta kestämätöntä. Esimerkiksi norsunluuta tai merikilpikonnan kilpeä ei voida enää käyttää lajeja vaarantamatta. Sama on tilanne puhaltimissa suositun hyvälaatuisen korkin ja luonnonkumin suhteen; jälkimmäisestä tehdään eboniittia, niin ikään uhanalaisen eebenpuun korviketta. Monien ei-uhanalaistenkin metallien ja mineraalien käyttö edellyttää voimakasta kaivostoimintaa, joka käyttää pääosin fossiilisia eli ei-uusiutuvia energianlähteitä. Sama epäsuora ympäristöhaitta seuraa uhanalaisista aineksista valmistettujen soitinten osien, kuten ruusupuisten lyömäsoitinten kielien, korvaamisesta synteettisesti valmistetuilla materiaaleilla, kuten öljystä valmistettavalla muovilla. (Allen \& Libin [tulossa]; Allen 2011b.) Nykyään soitinrakennuksessa käytettyjen puulajien alkuperää tarkkaillaan viranomaisten toimesta, ja puulajien hankkiminen sellaisilta alueilta, joilla kyseiset lajit - esimerkiksi mahonki, ruusupuu ja pernambuco - ovat uhanalaisia, on ainakin Länsimaissa pääsääntöisesti lainvastainen teko. Esimerkiksi Gibson-kitaravalmistajan tehtaalle tehtiin jokin aika sitten, eikä suinkaan ensimmäistä kertaa, viranomaisratsia tällaisten epäilyjen vuoksi (Havighurst 2011).

Kestävyyden näkökulmasta voidaan ekomusikologisesti tarttua myös vaikka suurten rock-yhtyeiden kiertueiden ympäristövaikutuksiin. Esimerkiksi U2-yhtyeen vuosina 2009-2011 tekemän 360'-kiertueen on arvioitu tuottaneen hiilidioksidi- ja muita kasvihuonepäästöjä siinä määrin, että niiden paikkaaminen olisi vaatinut noin 20000 puun istuttamista. Toisaalta, kuten mainittu, Radioheadin 
kaltaiset yhtyeet ja artistit ovat pyrkineet tuottamaan hiilidioksidineutraaleita konsertteja ja siten lisäämään ilmastonmuutosta koskevaa tietoisuutta. (Pedelty 2011 \& 2012.) Musiikin ja musiikintutkimuksen suhdetta ilmastonmuutokseen on historiallisessa ja filosofisessa perspektiivissä tarkastellut muun muassa Annette Kreutziger-Herr (2012).

\section{Topofilia ja paikallisuus}

Paikka ja paikallisuus ovat olleet musiikin ja musiikintutkimuksen keskeisiä teemoja aina antiikin maantieteellisistä asteikkonimistä (doorinen, lyydinen, fryyginen) etnomusikologiaan, jolle kysymys paikallisuuden ja musiikillisen kulttuuri-identiteetin välisestä suhteesta on ollut aina tärkeä. Ekomusikologinen tutkimus antaa musiikin paikallisuudelle uudenlaisen painon: paikan kategoriaa musiikissa on alettu tarkastella luonnonympäristön kriittisen tilan näkökulmasta (Cooley 2009).

'Paikka' ei ole yksiselitteinen tai ongelmaton käsite. Se voi tarkoittaa samanaikaisesti ainakin kolmea asiaa: 1) materiaalista luonnonympäristöä, 2) sosiaalista konstruktiota sekä 3) yksilöllistä affektia ja kytköstä (ks. Guy 2009: 219). Musiikintutkimus on perinteisesti kiinnittänyt huomiota paikallisuuteen erityisesti yhteisöllisenä musiikillisen konstruktion muotona (esimerkiksi kansalliset tyylit musiikissa). Se on kuitenkin jättänyt vähemmälle huomiolle paikallisuuden materiaalis-fyysisenä todellisuutena sekä paikallisuuden yksilöllisenä, affektiivisena kytköksenä (Guy 2009: 219). Edellä tehty kolmijako voidaan rinnastaa Guattarin kolmen ekologisen piirin yhteenkuuluvuuden periaatteeseen: mikään paikallisuuden yksittäinen ulottuvuus ei toimi muista irrallisena. Materiaalis-fyysinen paikallisuus (paikallinen luonnonympäristö) on aina sekä kulttuurisen artikulaation että yksilöllisen kokemuksellisuuden lähde ja kohde.

Ekomusikologia pohtii sitä, voiko 'paikasta' tulla etnisyyden, yhteiskuntaluokan ja sukupuolen kaltainen kriittinen (kritisistinen) käsite (vrt. Glotfelty 1996: xix). Etnomusikologian klassikkoesimerkki paikan ja luonnon "akustemologisesta" kytkeytymisestä äänelliseen kommunikaatioon on Steven Feldin Sound and Sentiment: Birds, Weeping, Poetics, and Song in Kaluli Expression (1982; ks. myös Feld 1994; Ramnarie 2009). Aaron S. Allenin [tulossa] mukaan ekomusikologinen tutkimuksen peruseetos on kuitenkin poliittisempi ja kriittisempi kuin esimerkiksi Feldin tutkimusta luonnehtiva kuvaileva ja tulkinnallinen ote. 
Tällaisesta kriittisestä lähestymistavasta paikallisuuteen voi mainita esimerkiksi Nancy Guyn (2009) tutkimuksen taiwanilaisesta populaarimusiikista. Guy on tutkinut ekokriittisestä näkökulmasta, miten pääkaupunki Taipeista satamakaupunki Tamsuihin virtaavaa "kerran elävää, nykyisin myrkyllistä" Tamsui-jokea on kuvattu taiwanilaisessa populaarimusiikissa. Erityisesti Guy pohtii sitä, miten laulut auttavat ymmärtämään muutosta paikallisten ihmisten affektiivisessa suhteessa jokeen ja laajemmin koko fyysiseen ympäristöönsä. Hänen mukaansa vanhemmissa 1930-1950-luvun lauluissa joki näyttäytyi elämän ja toimeliaisuuden keskuksena. Sen jälkeen, aina 1980-luvulle asti, joesta laulettiin ympäristöllisen ilmiön sijaan lähinnä rakastettujen kohtaamispaikkana; yleisen taloudellisen kasvun myötä "maasta tuli abstraktia ja taloudesta konkreettista" (Guy 2009: 242). 1980-luvulta alkaen taas joki on näyttäytynyt enenevässä määrin merkkinä luonnon vaarantumisesta. Laulujen joki on siis muuttunut elämän keskuksesta saastuneeksi, vaaralliseksi ja ihmisille etäiseksi paikaksi. (Guy 2009.)

Ekomusikologisessa tutkimuksessa paikallisuuden näkökulma voi tarkoittaa myös sitä, että tutkimuksen kohteena olevat musiikilliset käsitteet ja musiikilliset (luovat) prosessit nähdään suoraan välittömän luonnonympäristön muokkaamina (ks. esim. Ramnarie 2009: 187). Ilmeinen esimerkki on pohjoiset ja erityisesti arktiset alueet, jotka globaalissa mittakaavassa saattavat näyttäytyä vielä suhteellisen koskemattomina ja ympäristöltään puhtaina alueina, mutta jotka toisaalta ovat esimerkiksi ilmastonmuutoksen aiheuttaman jäätiköiden sulamisen myötä erittäin suurten muutosten kourissa. Pohjoisuuden vaikutusta ja ilmenemistä on tutkittu esimerkiksi saamelaisen taiteilijan Nils-Aslak Valkeapään "akustemologiassa" (Ramnarie 2009), alaskalaisen säveltään John Luther Adamsin ympäristöön sulauttavassa "subjektittomassa" musiikissa ja estetiikassa (Torvinen [tulossa]; ks. myös Adams 2009; Morris 1999); Kalevi Ahon ympäristömusiikissa (Välimäki 2009); kanadalaisen pianistin Glenn Gouldin estetiikassa (Mantere 2006); Edward Griegin ja Jean Sibeliuksen soivissa mentaalimaisemissa (Grimley 2006 \& 2011; ks. myös Watkins 2011); suomalaisessa raskaassa rockissa (Richardson 2008); tai Björkin ja Sigur Rósin avantgarde-popissa (Dibben 2009; Richardson 2012: 274-281).

Musiikin paikallisuutta voidaan lähestyä myös, filosofian termein sanottuna, ideana tai tyyppinä eikä minään yksittäisenä kotiseutuna tai luonnonkolkkana. Esimerkiksi "Varrella virran" -laulussa ei olla minkään tietyn virran rannalla vaan ikään kuin kaikkien mahdollisten saasteongelmasta kärsivien virto- 
jen rannalla. Samoin lukuisat musiikilliset toteutukset Fransiskus Assisilaisen (1181/1182-1226) Aurinkolaulusta (1224/1225; mm. Franz Liszt, William Walton, Sofia Gubaidulina, Jouni Kaipainen) eivät koske minkään tietyn luonnonympäristön eläin- tai kasvijoukkoa vaan ylistävät mitä tahansa elävää missä tahansa paikassa. Mutta tällaisissakin tapauksissa sanoman mielekkyys kuitenkin nousee paikallisuudesta, yksittäisen ihmisen konkreettisista ja affektiivisista kokemuksista; meillä ei ole lähtökohtaista kokemusta voikukan tai varpusen "tyypistä" vaan ainoastaan voikukan tai varpusen "esiintymistä".

Kiinteä suhde paikalliseen ympäristöön, maisemaan ja kotiseutuun on topofiliaa. Termi viittaa ihmisen affektiiviseen ympäristösuhteeseen, joka sisältää niin kauneuden kokemuksia, hyvänolon tunteita kuin usein lapsuuteen asti juontuvaa kotiseuturakkautta tai "kaipuuta juurille". (Hollsten 2008: 75.) Nykyisessä ympäristökatastrofien tilanteessa tämä yksilöllinen suhde ja sen materiaaliset edellytykset ovat uhattuina. Juuri siksi paikallisuus henkilökohtaisena luontosuhteena on omiaan herättämään huolta luonnon tilasta ylipäätään. Toinen syy paikallisuuden positiiviseen merkitykseen ympäristötietoisuuden kannalta on se, että ollessaan kuvaannollisesti ja konkreettisesti lähellä luontoa, ihminen yksinkertaisesti havaitsee ympäristön muutokset paremmin. Kolmas tekijä on se, että paikallisuus vastustaa rakenteellisesti, kielellisesti ja kulttuurisesti sellaisia ideologisia ja filosofisia rakenteita (kuten tiede ja talouskasvun ihannointi), jotka toimivat vain ainutkertaisista tilanteista ja paikoista irrotetussa abstrahoidussa ja ideaalissa todellisuudessa. (Paikallisuudesta filosofis-ekologiselta kannalta ks. esim. Vadén 2010.)

Kuten kirjallisuudentutkija Anna Hollsten (2008: 74) aiheellisesti toteaa, paikallisuuden korostaminen (topofilia) voi näyttäytyä nurkkakuntaisena kotiseuturakkautena, jolloin kiinnostus globaaleihin ympäristökysymyksiin on vaarassa jäädä paikallisten intressien varjoon. Paikallisuus on omiaan herättämään myös nationalismi-syytöksiä. Siksi etäinenkin analogia vaikkapa natsien Blut und Boden -ideologiaan on vaatinut eurooppalaisilta paikallisuuden tutkijoilta, muuallakin kuin Saksassa, tietoista ja eksplikoitua erottautumista paikallisuuden ja kansallismielisyyden yhdistämisestä. Yhdysvaltalaisessa ympäristötietoudessa vastaavanlainen paikallisuus on kuitenkin ollut varsin ongelmattomasti yksi pääperiaate (Rigby \& Goodbody 2011: 3). Esimerkiksi Martin Heideggerin maalaiselämää ja luonnonläheistä asumista korostavia ajatuksia saatetaan lukea tietyn biografisen, Heideggerin Heideggerin natsiyhteyksiä korostavan linssin läpi (ks. 
esim. Garrard 2012 [2004]: 120-122), vaikka ympäristösuhteen kannalta vastaavia ajatuksia löytyy muun muassa amerikkalaisilta Henry Thoreaulta ja Ralph Waldo Emersonilta (ks. Buell 1995: 510-511; Emerson 2002 [1836]).

Paikallisuudesta kumpuavasta kokemuksellisuudesta toki voi nousta, mutta ei millään loogisella välttämättömyydellä väistämättä nouse kansallismielinen, ajattelu. Yhtä hyvin siitä nousee tai ei nouse "maapallomielinen", "luontomielinen" tai ekokriittinen ajattelu. Guattarin ekologisissa piireissä ja Buellin paikallisuuden ulottuvuuksissa nationalismi liittyy lähinnä sosio-kulttuurisen alueelle. Mutta viimeistään ympäristökriisien noustua humanististen alojen tutkimuskohteeksi on paikallinen luontokokemus alkanut suunnata huomiotamme myös materiaalis-fyysisen ja yksilöllis-kokemuksellisen ekologisille kehille.

\section{Affektiivisuus}

Paikkaan ja paikallisuuteen liittyy myös ekomusikologian kokemuksellinen ulottuvuus. Edellä kävi ilmi, että affektiivisuus ja kokemuksellisuus on olennainen osa ekomusikologian tapaa ymmärtää musiikki ja tutkimus. Ekokriittisessä kirjallisuudentutkimuksessa affektiivisuus tarkoittaa kirjallisuudentutkija Karoliina Lummaan (2008: 56-57) mukaan pyrkimystä tuoda tutkijan emotionaalinen ympäristösuhde ja ympäristön tilan hänessä herättämät huolen ja surun tunteet osaksi tutkimusta ja tutkimustekstiä. Tällä tavoitellaan tutkimuksen suurempaa vaikuttavuutta: affektiivisuuden tuominen esille vahvistaa vaikutelmaa siitä, että tutkija on aidosti ympäristöstä huolissaan. On tosin esitetty, että emotionaalinen suhde luontoon olisi pateettista harhaa (engl. pathetic fallacy), antroposentristä tunteiden projisointia luontoon ilman, että luonnolla olisi tässä mitään kummempaa sanavaltaa. Mutta toisaalta on myös esitetty, että ihmisen sisäisen maailman peilautuminen luontoon on sitä, että näemme itsemme luonnon kanssa jatkumossa, osana luontoa. (Hollsten 2008: 87-88.)

Ekomusikologian kannalta kokemuksen käsite nojaa erityisesti seuraavan kaltaisiin fenomenologisesti sävyttyneisiin määritelmiin. Ensinnäkin 'kokemus' on tässä-ja-nyt vaikuttavaa kokonaisvaltaista maailmasuhdetta ja subjektin affektiivista kytkeytymistä asioihin, olioihin, mentaalisiin ja fyysisiin ilmiöihin. (Vastakohtana 'kokemus' esimerkiksi saksan kielen Erfahrung-termiä lähellä olevassa merkityksessä, elämän- ja henkilöhistoriallisesti kertyneenä aineksena.) Toisek- 
si ekomusikologialle ominaisen kokemuksen kohde (materiaalinen ja fyysinen luonnonympäristö) tarjoaa näkökulman (luonto, ympäristö, ekologiset kriisit), joka ei edusta samanlaista alistettua toiseutta kuin musiikintutkimuksen paljon käsittelemät etnisyyden, sukupuolen, kansallisuuden ja luokan kategoriat, joihin tutkijan on helppo identifioida itsensä. (Vrt. Lummaa 2008: 56.) Ekomusikologian näkökulmasta kokemuksellisuus on kokonaisuus, jossa yhdistyvät yliyksilöllinen ja a-subjektiivinen fyysisyys (ihmisestä riippumaton luonnonympäristö), yhteisöllisyys ja kulttuurisuus (luonto kulttuurisena konstruktiona, musiikki kulttuurisena käytäntönä) sekä subjektiivinen affektiivisuuden (kokemuksellisuuden) piiri.

Kokemuksellisuus voi siis olla osa tutkimuksen tekemisen tapaa, kieltä ja retoriikkaa. Samoin kokemuksellisuus voi olla tutkimuksen kohde. Erilaisissa yksittäisissä ekologisissa tilanteissa törmätään luonnollisesti valtavaan kokemusten kirjoon. Havainnollisuuden vuoksi ekomusikologisesta kokemuksellisuudesta voidaan erottaa kaksi perustyyppiä, jotka voivat olla paitsi musiikin ja tutkimuksen tekemisen motiiveja myös seikkoja, joihin ekologinen musiikki ja ekomusikologinen tutkimus pyrkivät kiinnittämään huomiomme ekokriittisten tarkoitusperien toteutumiseksi.

Ensimmäinen kokemustyyppi on huomion kiinnittymistä siihen yksinkertaiseen seikkaan, että ympäristössä on jotain vialla. Fenomenologi ja paikan estetiikan filosofi Edward S. Casey (2003) on analysoinut levinasilaisittain, kuinka vilkaisu (engl. glance) sellaisenaan, ei analysoituna tai tulkittuna näköhavaintona, voi olla ympäristön ongelmien ymmärtämisen lähtökohta. Kyse on anomalian, epäkohdan tai jonkinlaisen "kokemuksellisen katkoksen" havaitsemisesta. Caseyn näkemyksen mukaan jokainen ilmiö ja asia saa mielekkyytensä siitä paikasta, jota se "asuttaa", ja häiriöillä on tässä kokonaisuudessa aina eettisesti velvoittava luonne. (Antiikin Kreikassa ethos tarkoitti alun perin eläinten asuinja lepopaikkaa.) Tässä mielessä musiikilla ja ympäristön äänillä on erityisasema Caseyn ja Levinasin analysoimaan katseeseen verrattuna: ääni ympäröi, vaikuttaa kehollisina tuntemuksina (värähtelyinä), eikä korvia voi sulkea kuten silmiä. Poikkeus ääniympäristössä, joko luonnon äänissä tai musiikissa, voidaan kuulla eettisesti velvoittavana ekologisena indikaattorina ja herätteenä.

Hyvän esimerkin siitä, kuinka muutokset ääniympäristössämme kiinnittävät huomion ekologisiin kysymyksiin, antaa John Richardsonin (2011: 274-281) analyysi islantilaisen folk rock -yhtye Sigur Rósin kappaleesta "Heysátan", joka 
on osa Dean DeBlois'n elokuvaa Heima (2007). Samalla analyysi havainnollistaa, kuinka tietty maantieteellinen paikka ja luonnonympäristön erityisyys, tila ja tulevaisuus voivat vaikuttaa musiikkiin. Jotkut piirteet elokuvassa ovat ekologisuudessaan hyvinkin ilmeisiä (elokuva ottaa kantaa Kárahnjúkarin vesivoimalan ympäristövaikutuksiin, yhtye soittaa luonnon keskellä), mutta kokemuksellisuuden kannalta kiinnostavinta on itse kappale ja erityisesti siihen kuuluvat hyvin pitkät tauot. Taukojen aikana kuullaan luonnon ääniä (tuulen suhinaa, lintujen laulua), mikä korostaa jatkuvuutta muusikoiden, musiikin ja fyysisen ympäristön välillä. Juuri taukojen ansiosta tämä jatkuvuus laajenee myös kuulijan kokemuksellisuuteen: musiikin ekologis-eettinen velvoittavuus juontuu tässä tapauksessa nähdäkseni siitä, että pitkät hiljaisuudet paitsi kiinnittävät huomiomme kuuntelemisemme ja musiikin ympäristösidonnaisuuteen (ja ympäristön mahdollisiin epäkohtiin) myös koettelevat sitä rajaa, jossa musiikin sisäinen hiljaisuus (tauko) on muuttumassa musiikkia ympäröiväksi hiljaisuudeksi. Tämä raja sinänsä on periaatteessa ahdistava, koska se ei ole enää musiikin todellisuuden täyttämää mutta ei vielä arkitodellisuuden kyllästämää (ks. myös Torvinen 2009a). Voi sanoa, että tämä rajapinta sinänsä osoittaa fundamentaalin ympäristöriippuvuutemme: häivähtävän tilan, jossa emme ole olemassa erillisinä subjekteina.

Toinen musiikin ekologinen kokemustyyppi nostaa viime mainitun seikan keskiöön tavalla, joka muistuttaa amerikkalaisen biologin Barry Commonerin luonnostelemaa ekologian ensimmäistä lakia: kaikki on yhteydessä kaikkeen muuhun (Lahtinen \& Lehtimäki 2008b: 13; ks. myös Adams 2009: 1). Musiikki ei tämän kokemuksellisuuden tapauksessa kiinnitä huomiotamme johonkin (potentiaaliseen) ympäristölliseen epäkohtaan sinänsä vaan nostattaa suoran kokemuksen siitä, että kaikki on yhteydessä toisiinsa. Tällainen uppoutuva tai sulauttava kuunteleminen (engl. immersive listening) voi mystisimmillään liittyä "kosmiseen tietoisuuteen" ja psykoanalyyttisimmillaan musiikin kykyyn tuottaa valtamerellinen fantasia alkuperäisestä yhteydestä äitiin ja olemassaolon kokonaisuuteen. Tällaisilla kokemuksilla voi olla myös poliittisesti kumouksellisia seurauksia, sillä porvarillinen yhteiskunta perustuu juuri erillisen yksilön ajatukselle (Ingram 2010: 62).

Paikallisuuden ja luonnonympäristön kontekstissa musiikin herättämä kokonaisvaltainen, egokeskeisyydestä irtautuva asubjektiivinen kokemus voi kohdentua primaarin narsismin tai kosmisen tietoisuuden sijaan ekokeskeisyyteen. 
Olen toisaalla analysoinut, kuinka tämä periaate on sekä esteettis-filosofisena lähtökohtana että musiikin kokemuksellisena peruslaatuna hallitseva John Luther Adamsin sävellyksissä, joita luonnehtii (musiikillisen) subjektiuden, etualatausta-tyyppisten teksturaalisten jaottelujen sekä lineaariseen (orgaaniseen) kehitykseen perustuvien musiikillisten prosessien välttäminen (Torvinen [tulossa]; ks. myös Morris 1999). Adamsin pohjoisesta (Alaskan) luonnonympäristöstä kumpuava ekologinen musiikki osoittaa, kuinka musiikki tietyssä mielessä on paikka (ks. Watkins 2011: 405). Musiikki voi tuoda ajan ja paikan esille välittömänä kokemuksena eikä representaationa tai yhteisöllisesti sovittujen merkityskäytäntöjen kautta. Musiikki voi olla ekologista kokemuksellisena laatuna sinänsä. Näin ollen musiikki voi liittyä ekologisiin kriiseihin tavalla, jolla myös virtuaalitodellisuus Timothy Mortonin (2007: 26-27) mukaan niihin liittyy: molemmissa on kyse sulauttavista kokemuksista, joissa totunnaiset tietämisen tavat ja ehdot (kuten länsimainen etäisyyttä vaativa subjekti-objekti-jaottelu) kumoutuvat tai asettuvat vähintäänkin kyseenalaisiksi.

\section{Ekokriittinen ylitulkinta}

Vaikka suhde paikallisuuteen tai maantieteelliseen ja ympäristölliseen erityisyyteen on usein ainakin epäsuorasti ekomusikologisen tutkimuksen taustalla, on paikkasidonnaisuus (topofilia) on kuitenkin vain yksi ekokriittisen musiikin ja musiikintutkimuksen teema. Näin siitäkin huolimatta, että suhde paikallisuuteen tai maantieteelliseen ja ympäristölliseen erityisyyteen on usein ainakin epäsuorasti ekomusikologisen tutkimuksen taustalla. Ekomusikologian kohteet ovat moninaisemmat. Scott Slovicin (2000: 160) ekokriittisen kirjallisuudentutkimuksen määritelmän mukaan ympäristötekstejä voi tutkia millä tahansa välineillä ja, vastaavasti, mitä tahansa kirjallista tekstiä voi tutkia ympäristöllisiä merkityksiä kantavana ilmiönä. Jos määritelmää sovelletaan musiikintutkimukseen, voidaan sanoa, että ekomusikologian kohteena voi olla mikä tahansa musiikki tai musiikillinen käytäntö, jota kuunnellaan/tutkitaan/tulkitaan ekokriittisestä lähtökohdasta mitä tahansa menetelmiä hyväksi käyttäen.

Tutkimuksen kohteesta (musiikista tai musiikillisista käytännöistä) tai menetelmistä tämä määritelmä ei sano mitään konkreettista. Se on ongelma vain, jos 
tutkimuksen toteutuksen edellytyksenä pidetään vahvoja (ja usein myös tunnistamattomia ja erittelemättömiä) ontologisia ennakko-oletuksia kohteen (musiikin tai musiikillisten käytäntöjen) luonteesta ja tutkimuksen tekemisen tavoista - koskien esimerkiksi musiikin välttämättömiä ehtoja tai tutkimuksen validiuden ja reliabiliteetin kriteereitä. Ekomusikologiassa näihin seikkoihin kiinnitetään huomiota vain siinä määrin kuin ne valaisevat alan perusmotivaatiota eli ympäristön tilaan liittyvää huolta ja kantaaottavuutta. Musiikki ymmärretään inhimillisenä toimintana ja kulttuurina, ja silloin, kun tämä toiminta ja sen tuotokset asetetaan ekokriittisen tarkastelun alle, voidaan muodostunutta tutkimuskohdetta kutsua ekomusiikiksi (ks. Välimäki 2009; 2012). Ekomusiikki ei siis ole termi, joka määrittelee tai essentialisoi kohteensa objektiivisesti asettaen sille joitain välttämättömiä ehtoja tai kriteerejä. Sen sijaan kyseessä on operatiivinen käsite, joka viittaa siihen, että tutkimuskohde tematisoituu aina yksittäisissä tapauksissa erikseen edellä mainitun poliittisen ja aktivistisen orientaation määräämällä tavalla.

Ekomusiikiksi voidaan - ainakin periaatteessa - lukea ja ekokriittisesti voidaan kuunnella "mitä tahansa" musiikkia aina eläinten musiikillisesta käyttäytymisestä (Martinelli 2002; Rothenberg 2008) äänitaiteeseen (esim. Petri Kuljuntaustan tuotanto) ja populaarimusiikista (esim. Ingram 2010) kansanmusiikkiin. Hyvänä esimerkkinä ekomusikologisesta kuuntelusta toimii Välimäen (2009; 2012) analyysit ekologisista teemoista suomalaisessa klassisessa nykymusiikissa ja hip hopissa. Sävellyksiä (esimerkiksi Pehr Henrik Nordgrenin Agnus deita, Kalevi Ahon Luostosinfoniaa ja Aulis Sallisen konserttoa klarinetille, alttoviululle ja kamariorkesterille) tulkitaan nykymusiikin "ekologisen käänteen" ilmentäjinä: tällainen ympäristökriittinen musiikki kysyy, onko ihmiskunnalla olemassa muita kuin ympäristöä tuhoavia tapoja olla olemassa. (Välimäki 2009.)

Ekomusiikiksi voidaan siis tulkita myös musiikkia, jolla ei ole eksplisiittistä ekologista tai ekokriittistä sisältöä tai joka ei tekoajankohtansa, tekijän intentioiden tai jonkin määrätyn sisältönsä suhteen ole osoitettavissa suoranaisen ekokriittiseksi. Sitä voidaan kuitenkin kuunnella ekomusiikkina, jolloin voidaan esimerkiksi kuunnella Brooks Toliverin (2011) tapaan Richard Straussin Alppisinfoniaa pohtien, miten se on vaikuttanut käsityksiimme Alppien vuoristosta tai vuoristoista yleensä (ks. myös Mellers 2001; Grimley 2006). Voimme myös antaa musiikin kertoa luonnonympäristöistä, joita ei sellaisenaan enää ole olemassa. Onko esimerkiksi Uuno Klamin Merikuvien (op. 22, 1930-1932) Suomenlahti se 
sama saastunut meri, jonka tänään tunnemme? (Ks. myös Lahtinen \& Lehtimäki 2008b: 12.) Ekomusikologiaan voidaan liittää monenlaisia musiikinhistoriallisia sivujuonteita. Lisäksi, ekomusikologista kuuntelua voidaan harjoittaa musiikin välitöntä kokemusmaailmaa tarkastellen. Esimerkiksi saksalaisen Tangerine Dream -yhtyeen Zeit-levyn (1972) "esi-ambientin" akustiset atmosfäärit on mahdollista kokea ympäristöön sulauttavina affektiivisina "kenttinä" sekä ekologisen kaikki liittyy kaikkeen -perusajatuksen representaatioina, vaikka levy ei otakaan eksplisiittisesti kantaa ympäristöongelmiin.

Ekomusikologian kohteena oleva ekomusiikki ei rajoitu musiikkiin vain soivana ilmiönä. Myös monet musiikkiin ja musiikin tekemiseen ja kuuntelemiseen liittyvät ekologisuutta korostavat käytännöt voivat olla ekomusikologisen tarkastelun kohteita ja siten ekomusiikkia. Tutkimuskohteena voi olla esimerkiksi c-kasettien käyttö, vanhojen soittimien kierrättäminen tai ei-soittimien käyttö musiikin tekemisen välineinä. Tässä hengessä ekomusikologia jakaa sen Timothy Mortonin (2007) propagoiman ajatuksen, jonka mukaan 'luonto', erityisesti sen romanttisessa merkityksessä, saattaa olla rajoite ekologiselle ajattelulle. Ympäristöön kuuluu paitsi ihmisestä riippumaton luonnonympäristö myös rakennettu ympäristö ja kaikki epämiellyttävä, kuten jätteet ja saasteet. Näiden kaikkien kanssa on tultava toimeen, sillä myös ne ovat osa sitä kokonaisuutta, jonka osia itsekin olemme. Haastaessaan ja purkaessaan ympäristöön ja luontoon liittyviä käsityksiä ja metafyysisiä, usein itsestään selvinä pidettyjä kategorioita ekomusikologia muistuttaa queer-teoriaa: kuten queer-tutkimus voi nähdä kaiken pervona, näkee/ kuulee ekomusikologia kaikessa ympäristösuhteen (ks. Morton 2007: 13).

Ekomusikologian tapa rakentaa tutkimuskohteensa ekomusiikiksi tulkinnan prosessissa osoittaa, kuinka ekomusikologia on poliittis-aktivistisuudessaan tarkoitushakuista ja ylitulkitsevaa. Kirjallisuudentutkija Karoliina Lummaan (2008: 67) mukaan ylitulkinta on ekokriittisessä kirjallisuudentutkimuksessa perusteltua ja mielekästä juuri silloin, kun tulkinta perustellaan ja kontekstualisoidaan poliittisesti. Jos jokin musiikki tulkitaan ekomusiikiksi, siis ympäristökriittiseksi ääni-ilmiöksi, on tämä tulkinta ymmärrettävissä vain tämän päivän tilanteen motivoimana: ympäristökriisien nousu keskeisimmän tulevaisuuden uhkakuvan rooliin on ekomusikologian poliittis-aktivistisen peruseetoksen ydin, joka perustelee kohteiden ylitulkinnan poliittisen päämäärän tavoittamiseksi. Kontekstualisoinnin päämääränä ei siten ole mielivaltainen merkitysten suhteellisuuden 
ja kiinnittymättömyyden osoittaminen vaan tulkintojen sitominen siihen historialliseen tilanteeseen (nykypäivään), jossa luonnon monimuotoisuuden tuhoutuminen on todellinen ja kiihtyvällä vauhdilla etenevä uhka (Lummaa 2008: 55).

Lummaan käyttämää ylitulkinnan käsitettä ei kuitenkaan saa ymmärtää väärin siten, että sen oletettaisiin sisältävän ajatuksen, jonka mukaan olisi olemassa myös jokin varsinainen tai oikea tulkinta (joka ei olisi "yli"). Tästä ei ole kyse. Ekokritiikissä ja ekomusikologiassa on kyse ylitukinnasta vain siinä merkityksessä, että tulkinnan kohteen ylle heitetään kaikenkattava, tarkkaan valittu sekä poliittisesti ja filosofisesti perusteltu ajankohtainen tulkintakehys. Voiko mikään tulkinta olla liiallinen, jos sillä on pienikin positiivinen ekologinen vaikutus?

\section{Lopuksi}

Olen tarkastellut tässä artikkelissa sitä, mitä on ekomusikologia. Artikkelin päätteeksi ehdotan seuraavaa ekomusikologian määritelmää:

\footnotetext{
Ekomusikologia on ympäristökriisien motivoima kriittisen musiikintutkimuksen osa-alue, joka tutkii musiikkia ja äänellistä kulttuuria ihmisen ympäristö- ja luontosuhteen indikaattorina pyrkimyksenään ihmisen arvojen ja toiminnan muuttaminen ympäristön kannalta kestävämpään suuntaan.
}

Kuten kaikille tutkimusaloille on tavallista, myös ympäristökriiseistä huolta kantava musiikintutkimus osoittaa merkkejä jakaantumisesta eri tutkimussuuntauksiin. Sellaisia ovat esimerkiksi artikkelin alussa mainitut ympäristöetnomusikologia ja ekomusikologia, vaikka näillä ei mitään merkittävää sisällöllistä eroa ainakaan toistaiseksi olekaan. On kuitenkin mahdollista sekin, että ympäristökriisien kaikkiallisuuden ja fundamentaalisuuden vuoksi ekomusikologia toimii eri tutkimusja musiikkikäsityksiä yhdistävänä alueena, jossa tutkijoiden energia ei huku musiikkitieteellisten julkaisujen sivuilla tapahtuvaan väittelyyn ympäristökriittisen musiikintutkimuksen oikeista ja vääristä harjoittamisen tavoista. Onhan koko ajan olemassa se vaara, josta Rauli "Badding" Somerjoki lauloi Jarkko Laineen sanoin jo yli 40 vuotta sitten, että "maailma hukkuu paskaan, me vain luemme lehtiä". 


\section{Lähteet}

Adams, John Luther (2009) The Place Where You Go to Listen: In Search of an Ecology of Music. Middletown: Wesleyan University Press.

Allen, Aaron S. (2011a) "Ecomusicology: Ecocriticism and Musicology". Journal of the American Musicological Society 64:2, ss. 391-394.

Allen, Aaron S. (2011b) "Prospects and Problems for Ecomusicology in Confronting a Crisis of Culture". Journal of the American Musicological Society 64:2, ss. 414-419.

Allen, Aaron S. [tulossa]. "Ecomusicology". Grove Dictionary of American Music, Second Edition. Toim. Charles Hiroshima. New York: Oxford University Press.

Allen, Aaron S. \& Libin, Laurence [tulossa]. Sustainability. Grove Dictionary of Musical Instruments, Second Edition. Toim. Laurence Libin. New York: Oxford University Press.

Brown, Charles S. \& Toadvine, Ted (2003). "Eco-Phenomenology: An Introduction". EcoPhenomenology: Back to the Earth Itself. Toim. Charles S. Brown \& Ted Toadvine. New York: State University of New York Press. Ss. ix-xxi.

Buell, Lawrence (1995). The Environmental Imagination: Thoreau, Nature Writing, and the Formation of American Culture. Cambridge (ма) \& London: The Belknap Press of Harvard University Press.

Buell, Laurence (2005). The Future of Environmental Criticism: Environmental Crisis and Literary Imagination. Malden (MA): Blackwell.

Casey, Edward S. (2003). "Taking a Glance at the Environment: Preliminary Thoughts on a Promising Topic". Eco-Phenomenology: Back to the Earth Itself. Toim. Charles S. Brown \& Ted Toadvine. New York: State University of New York Press. Ss. 187-210.

Clarke, Eric F. 2005. The Ways of Listening: An Ecological Approach to Musical Meaning. Oxford (UK) \& New York: Oxford University Press.

Cooley, Timothy J. 2009. "From the Editor". Ethnomusicology 53:2, s. v.

Coupe, Laurence (toim.) (2000). The Green Studies Reader: from Romanticism to Ecocriticism. London \& New York: Routledge.

Coupe, Laurence (200ob). "General Introduction". The Green Studies Reader: from Romanticism to Ecocriticism. Toim. Laurence Coupe. London \& New York: Routledge. Ss. 1-8.

Dibben, Nicola (2009). "Nature and Nation: National Identity and Environmentalism in Icelandic Popular Music Video and Music Documentary". Ethnomusicology Forum 18 :1, ss. 131-151.

Emerson, Ralph Waldo (2002 [1836]). Luonto. Suom. Antti Immonen. Tampere: niin\&näin. 
Ethnomusicology Study Group 2012. <www.ams.esg.org>. (Luettu 10.8.2012.)

Feld, Steven (1982). Sound and Sentiment: Birds, Weeping, Poetics, and Song in Kaluli Expression. Philadephia: University of Pennsylvania Press.

Feld, Steven (1994). "From Ethnomusicology to Echo-muse-ecology: Reading R. Murray Schafer in the Papua New Guinea Rainforest". The Sounscape Newsletter 8, s. 9-13.

Garrard, Greg (2012 [2004]). Ecocriticism. 2. painos. London \& New York: Routledge.

Glotfelty, Cheryll (1996). "Introduction: Literary Studies in an Age of Environmental Crisis". The Ecocriticism Reader: Landmarks in Literary Ecology. Toim. Cheryll Glotfelty \& Harold Fromm. Athens \& London: The University of Georgia Press. Ss. xv-xxxvii.

Glotfelty, Cheryll \& Fromm, Harold (toim.) (1996). The Ecocriticism Reader: Landmarks in Literary Ecology. Athens \& London: The University of Georgia Press.

Goodbody, Axel \& Rigby, Kate (toim.) (2011). Ecocritical Theory: New European Approaches. Charlottesville \& London: University of Virginia Press.

Grimley, Daniel M. (2006). Grieg: Music, Landscape and Norwegian Identity. Woolbridge: The Boydell Press.

Grimley, Daniel M. (2011). "Music, Landscapel, Attunement: Listening to Sibelius's Tapiola". Journal of the American Musicological Society 64:2, ss. 394-398.

Guattari, Félix (2008 [1989]). Kolme ekologiaa. Suom. Anna Helle, Mikko Jakonen ja Eetu Virén. Helsinki: Tutkijaliitto.

Guy, Nancy (2009). "Flowing Down Taiwan's Tamsui River: Towards an Ecomusicology of the Environmental Imagination". Ethnomusicology 53:2, ss. 218-248.

Harley, A. M. (1996). "Notes On Music Ecology: As A New Research Paradigm". <http:/ / interact.uoregon.edu/MediaLIt/wfae/library/articles/harly_paradigm.pdf> (Luettu 13.8.2012.)

Havighurst, Craig (2011). "Why Gibson Guitar was Raided by the Justice Department?" <http:/ / www.npr.org/blogs/therecord/2011/08/31/140090116/why-gibson-guitar-was-raided-bythe-justice-department> (Luettu 11.1.2012.)

Hollsten, Anna (2008). "Jäähyväiset Takkulalle: Esimerkki ekokriittisestä lajiluennasta". Äänekäs kevät: ekokriittinen kirjallisuudentutkimus. Toim. Toni Lahtinen \& Markku Lehtimäki. Helsinki: sKs. Ss. 73-93.

Ingram, David (2010). Jukebox in the Garden: Ecocriticism And American Popular Music since 1960. Amsterdam \& New York, NY: Rodopi.

Kreutziger-Herr, Annette (2012). "Im Antropozän: Klimawandel, Natur und Musik". Neue Zeitschrift für Musik 1/2012, ss. 14-19. 
Lahtinen, Toni \& Lehtimäki, Markku (toim.) (2008a). Äänekäs kevät: ekokriittinen kirjallisuudentutkimus. Helsinki: sKs.

Lahtinen, Toni \& Lehtimäki, Markku (2008b). "Johdatus ekokriittiseen kirjallisuudentutkimukseen". Äänekäs kevät: ekokriittinen kirjallisuudentutkimus. Toim. Toni Lahtinen \& Markku Lehtimäki. Helsinki: sKs. Ss. 7-28.

Lummaa, Karoliina (2008). "Risto Rasan surulliset linnut: ekokriittisen tulkinnan mahdollisuuksia”. Äänekäs kevät: ekokriittinen kirjallisuudentutkimus. Toim. Toni Lahtinen \& Markku Lehtimäki. Helsinki: sKs. Ss. 50-72.

Lummaa, Karoliina,Vuorisalo, Timo \& Rönkä, Mia (2012). "Ympäristötutkimus - monta tiedettä, monta monitieteisyyttä". Monitieteinen ympäristötutkimus. Toim. Karoliina Lummaa, Mia Rönkä \& Timo Vuorisalo. Helsinki: Gaudeamus. Ss. 15-23.

Mantere, Markus (2006). Glenn Gould: viisi näkökulmaa pianistin muusikkouteen ja kulttuuriseen reseptioon. Helsinki: Suomen Etnomusikologinen Seura.

Martinelli, Dario (2002). How Musical is a Whale? Helsinki \& Imatra: International Semiotics Institute.

Mellers, Wilfrid (2001). Singing in the Wilderness: Music Ecology in the Twentieth Century. Urbana \& Chicago: University of Illinois Press.

Morris, Mitchell (1999). "Ecotopian Sounds, or, The Music of Luther Adams and Strong Environmentalism". Crosscurrents and Counterpoints: Offerings in Honor of Bengt Hambræus at 70. Toim. Per F. Broman, Nora Engebretsen \& Bo Alphonce. Skrifter från Musikvetenskapliga Avdelningen 51. Göteborg: Göteborgs Universitet. Ss. 129-141.

Morton, Timothy (2007). Ecology without Nature: Rethinking Environmental Aesthetics. Cambridge (MA) \& London: Harvard University Press.

Murray Schafer, Raymond (1994 [1977]). The Soundscape. Rochester: Destiny Books.

Pedelty, Mark (2011). "EcoMusicology". Momentum, Spring 2011. <http:/ / environment.umn. edu/momentum/>. (Luettu 16.9.2011).

Pedelty, Mark (2012). Ecomusicology: Rock, Folk, and the Environment. Philadelphia: Temple University Press.

Ramnarine, Tina K. (2009). "Acoustemology, Indigeneity, and Joik in Valkeapää's Symphonic Activism: Views from Europe's Arctic Fringes for Environmental Ethnomusicology". Ethnomusicology 53:2, ss. 187-217.

Rehding, Alexander (2002). "Eco-musicology". Journal of the Royal Musical Association 127:2, ss. 305-320. 
Rehding, Alexander (2011). "Ecomusicology between Apocalypse and Nostalgia". Journal of the American Musicological Society 64:2, ss. 409-414.

Richardson, John (2008). "Sonata Arctica or Hill Street Blues? Shifting Ideas of the North in Finnish Rock". Esitelmä Music and the Idea of the North -konferenssissa Leedsissä 7.9.2008.

Richardson, John (2011). An Eye for Music: Popular Music and the Audiovisual Surreal. Oxford: Oxford University Press.

Rigby, Kate \& Goodbody, Axel (2011). "Introduction". Ecocritical Theory: New European Approaches. Toim. Axel Goodbody \& Kate Rigby. Charlottesville \& London: University of Virginia Press. Ss. 1-14.

Rothenberg, David (2008). Thousand Mile Song: Whale Music in a Sea of Sound. New York: Basic Books.

Slovic, Scott (2000). "Ecocriticism: Containing Multitudes, Practicing Doctrine". The Green Studies Reader: from Romanticism to Ecocriticism. Toim. Laurence Coupe. London \& New York: Routledge. Ss. 160-162.

Sustainable Music 2012. Jeff Todd Titonin blogi. <http://sustainablemusic.blogspot.com/>. (Luettu 28.8.2012.)

Titon, Jeff Todd (2009). "Music and Sustainability: An Ecological Viewpoint". The World of Music vol 51:1, ss. 119-137.

Toliver, Brooks (2011). "The Alps, Richard Strauss's Alpine Symphony and Environmentalism". <http://www.ams-esg.org/resources/supplementary>. (Luettu 21.9.2011.)

Torvinen, Juha (2007). Musiikki ahdistuksen taitona: filosofinen tutkimus musiikin eksistentiaalisontologisesta merkityksestä. Helsinki: Suomen Musiikkitieteellinen Seura.

Torvinen, Juha (2009a). "Mistä hiljaisuus kertoo? Kokemuslähtöisiä huomioita konserttihiljaisuuden merkityksistä". Musiikki 3-4/2009, ss. 26-53.

Torvinen, Juha (toim.) (2009b). Music \& Ecology. Finnish Music Quarterly 3/2009. Helsinki: Gramex ry.

Torvinen, Juha [tulossa]. "The Ecology of the Northern Tone: a Phenomenological Approach with Examples from Erik Bergman and John Luther Adams". Music and the idea of the North. Toim. Rachel Cowgill et al. Aldershot: Ashgate.

Tähtinen, Tero (2010). "Suomentajan esipuhe". Gary Snyder Erämaan opetus. Suom. Tero Tähtinen. Turku: Savukeidas. Ss. 5-17.

Vadén, Tere (2010). Kaksijalkainen ympäristövallankumous: pamfletti synnyistä. Tampere: Osuuskunta Rohkean reunaan.

Välimäki, Susanna (2009). "Green Music". Finnish Music Quarterly 3/2009 ,ss. 18-23. 
Välimäki, Susanna (2012). "Ekokriittinen musiikkianalyysi". Esitelmä Suomen musiikintutkijoiden 16. symposiumissa Jyväskylässä 22.3.2012.

Vuorisalo, Timo (2012). "Johdanto". Monitieteinen ympäristötutkimus. Toim. Karoliina Lummaa et al. Helsinki: Gaudeamus. Ss. 27-30.

Watkins, Holly (2011). "Musical Ecologies of Place and Placelessness". Journal of the Americal Musicological Society 64:2, ss. 404-408. 